\title{
STUDI N-SPT MENGENAI DAYA DUKUNG TIANG PANCANG PADA KONSTRUKSI PILE SLAB PROYEK JALAN TOL JAKARTA-KUNCIRAN-CENGKARENG
}

\author{
Steven Prima ${ }^{1}$, Iwan B. Santoso ${ }^{2}$ dan Josephine Aristiti Setyarini ${ }^{3}$ \\ ${ }^{1}$ Program Studi Sarjana Teknik Sipil, Universitas Tarumanagara, Jl. Letjen S. Parman No.1 Jakarta \\ Email: stevenprima3@gmail.com \\ ${ }^{2}$ Program Studi Sarjana Teknik Sipil, Universitas Tarumanagara, Jl. Letjen S. Parman No.1 Jakarta \\ Email: iwsantoso@hotmail.com \\ ${ }^{2}$ Program Studi Sarjana Teknik Sipil, Universitas Tarumanagara, Jl. Letjen S. Parman No.1 Jakarta \\ Email: josephine.setyarini@gmail.com
}

\begin{abstract}
ABSTRAK
Konstruksi pile slab dengan fondasi tiang pancang pada proyek jalan Tol Jakarta-KunciranCengkareng STA 37+826.7-STA 38.016.7 dengan ukuran diameter 0.6 m menggunakan 5 data borlog yang terbagi di 5 zona. Borlog tersebut menghasilkan data berupa N-SPT yang dapat digunakan untuk analisa perhitungan daya dukung tiang. Fondasi tiang pancang pada proyek ini berada pada kedalaman tanah keras berupa clay dengan rata-rata kedalaman $13 \mathrm{~m}$ dan rata-rata N-SPT 25. Metode koreksi NSPT yang digunakan dalam tulisan ini yaitu metode Tokimastu dan Yoshimi; Liao dan Whitman; Skempton; Peck, Hansen, dan Thornburn; Bazaraa; dan Skempton (Efisiensi). Sedangkan analisis daya dukung tiang yang digunakan dalam tulisan ini yaitu metode Schmertmann, Brown, dan Meyerhoff. Kajian secara teknis konstruksi pile slab dengan fondasi tiang pancang pada STA 37+826.7-STA 38.016.7 jalan Tol Jakarta-Kunciran-Cengkareng sehingga fondasi tiang tersebut dapat dikatakan efisien dan aman dilihat dari kedalaman tiang dan kapasitas daya dukung tiang.
\end{abstract}

Kata kunci: daya dukung tiang pancang, final set, N-SPT koreksi, PDA

\section{PENDAHULUAN}

Dikarenakan kebutuhan akses antar lokasi oleh populasi penduduk yang semakin tinggi, salah satu jenis infrastruktur yang mengalami perkembangan yang cukup pesat adalah jalan raya dan jalan bebas hambatan atau sering juga disebut sebagai jalan tol. Salah satu proyek jalan tol yang sedang berjalan saat ini adalah proyek jalan tol Jakarta-Kunciran-Cengkareng sepanjang STA 37+826.7 - STA 38+016.7 yang terdapat di Cipete. Semua jenis struktur, tidak terkecuali struktur jalan tol harus ditopang oleh suatu elemen utama, yaitu fondasi. Fondasi merupakan bagian dari struktur yang menyalurkan beban struktur atas ke dalam tanah. Fondasi yang digunakan di proyek ini adalah fondasi tiang pancang. Selain data N-SPT, desain fondasi juga memerlukan perhitungan dan analisis dari daya dukung tanah dan juga daya dukung tiang terhadap beban yang akan ditimbulkan dari jalan itu sendiri maupun kendaraan yang melintas di atasnya. Pada kondisi tertentu, terdapat berbagai faktor yang tidak diperhitungkan yang menyebabkan adanya perbedaan kedalaman pemancangan pada desain dan yang terjadi di lapangan. Perbedaan inilah yang mendorong adanya analisa daya dukung tiang pancang berdasarkan data - data penyelidikan tanah yang diperoleh di lapangan yaitu data SPT dan kalendering / final set dengan menggunakan metode yang disarankan oleh para ahli serta PDA tes dan program Allpile.

\section{Batasan Masalah}

- Data penyelidikan tanah yang diperoleh yaitu borlog sebanyak 5 titik yang dilakukan pada tahun 2017.

- Lokasi yang ditinjau dari STA 37+826.7 - STA 38+016.7 pada lokasi di Cipete.

- Analisis daya dukung dinamik menggunakan metode Meyerhoff (1976), metode Modified New ENR, Danish Formula, Janbu's Formula, dan berdasarkan data tes PDA (Pile Driving Analyzer).

- Analisis daya dukung statik menggunakan metode Schmertmann (1967), Brown (2006), dan Meyerhoff.

- Analisis N-SPT koreksi menggunakan metode Tokimastu dan Yoshimi; Liao dan Whitman; Skempton; Peck, Hansen, dan Thornburn; Bazaraa; dan Skempton (Efisiensi).

- Beban yang diperhitungkan hanya akibat beban aksial. 


\section{Tujuan Penelitian}

Tujuan penelitian ini adalah untuk mengkaji secara teknis apakah desain fondasi yang digunakan pada kontruksi pile slab efisien dan aman serta membuat perhitungan dengan menggunakan bantuan program Excel untuk memudahkan perhitungan yang berulang-ulang.

\section{TINJAUAN PUSTAKA}

Penyelidikan tanah yang dilakukan di lapangan yaitu bisa sondir, uji boring, Standard Penetration Test (SPT), dan lain-lain. Peninjauan langsung di lapangan untuk penyelidikan tanah sendiri dibagi menjadi tiga tahapan yaitu boring, sampling, dan testing (Gunawan, 1983). Umumnya cara penyelidikan tanah dapat digologkan berdasarkan pengambilan contoh yaitu terganggu dan tak terganggu. Biasanya empat sampai lima pemboran sudah cukup dilakukan untuk menetukan apakah tanahnya tak beraturan. Namun biasanya pada daerah yang memiliki permukaan tanah yang sangat tidak rata atau daerah - daerah yang pernah diurug, mungkin diperlukan jumlah pemboran yang lebih banyak (Bowles, 1988). Standard penetration test merupakan suatu percobaan yang dilakukan secara langsung di lapangan untuk memeperoleh daya dukung tanah dengan cara memasukan tabung sampel (split spoon). Banyaknya pukulan palu untuk memasukan split spoon dinyatakan dalam N. Berdasarkan jumlah pukulan yang didapatkan, diperoleh kerapatan relatif (relative desity) sehingga diketahui jenis tanah, untuk ketebalan tiap - tiap lapisan tanah, memperoleh data yang kualitatif pada perlawanan penetrasi tanah serta menetapkan kepadatan dari tanah yang tidak berkohesi yang biasa sulit diambil sampelnya dan juga sudut geser $(\phi)$.

\section{METODOLOGI PENELITIAN}

Dalam penelitian ini dilakukan beberapa tahapan yang dapat diuraikan sebagai berikut:

Tahapan pertama adalah melakukan pengumpulan data berdasarkan hasil peninjauan langsung di lapangan yaitu berupa data hasil tes SPT (Standard Penetration Test) dan data pemacangan tiang dengan melakukan pengamatan, pencatatan serta wawancara, sehingga data yang diperoleh sesuai.

Tahapan kedua adalah pengelolaan data menggunakan program Microsoft Excel untuk memperoleh daya dukung aksial fondasi tiang dengan metode statik, dinamik dan hasil PDA test.

Tahapan ketiga adalah analisis terhadap hasil perhitungan daya dukung.

Tahapan keempat adalah menarik kesimpulan.

\section{ANALISIS DAN PEMBAHASAN}

Analisis daya dukung tiang yang dilakukan pada pada proyek jalan tol Jakarta-Kunciran-Cengkareng di Cipete ini mula-mula dibagi kedalam beberapa zona berdasarkan data yang diperoleh dari data lapangan melihat luasnya lokasi yang ditinjau yaitu STA 37+816.7 - STA 38+017.7. Pembagian zona didasarkan pada lokasi titik borlog yang ada sebagai berikut:

- Zona A, BL47RW5 terdiri dari PS 1 - PS 10

- Zona B, BL47D terdiri dari PS 11 - PS 17

- Zona C, BL47RW4 terdiri dari PS 18 - PS 24

- Zona D, BL47RW3 terdiri dari PS 25 - PS 31

- Zona E, BL47RW2 terdiri dari PS 32 - PS 38

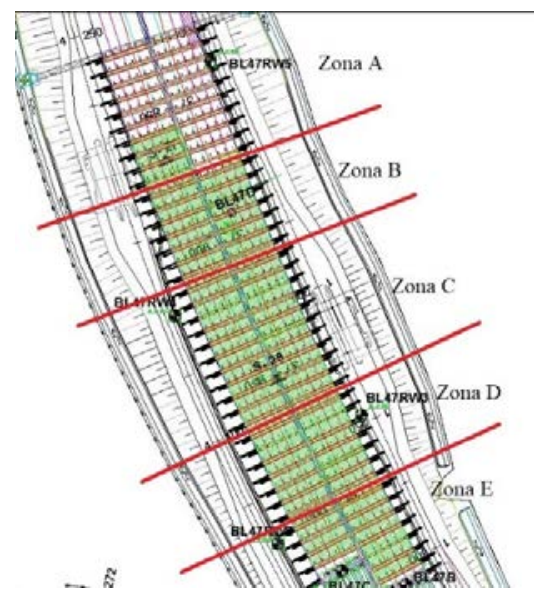

Gambar 1. Lokasi Pembagian Zona 
Selain menggunakan data hasil boring log, digunakan pula data hasil tes PDA yang dilakukan sebanyak 2 titik untuk melakukan pengecekan terhadap hasil analisis daya dukung tiang secara manual. Berikut dibawah ini merupakan hasil tes PDA yang diperoleh dari data lapangan dimana hasil tes ini belum direduksi faktor keamanan (SF=1).

Tabel 1. Hasil Tes PDA

\begin{tabular}{ccccc}
\hline \multirow{2}{*}{ No. Tiang } & \multicolumn{4}{c}{ CAPWAP } \\
\cline { 2 - 5 } & $\begin{array}{c}\text { Daya Dukung Total } \\
\text { Bearing Capacity } \\
\text { (Ton) }\end{array}$ & $\begin{array}{c}\text { Daya Dukung Friksi } \\
\text { Friction Capacity } \\
\text { (Ton) }\end{array}$ & $\begin{array}{c}\text { Daya Dukung Friksi } \\
\text { Friction Capacity } \\
\text { (Ton) }\end{array}$ & $\begin{array}{c}\text { Penurunan Settlement } \\
\text { (mm) }\end{array}$ \\
\hline PS-26R-6 & 434.0 & 200.1 & 233.9 & 13.7 \\
\hline PS-27R-6 & 461.0 & 146.5 & 314.5 & 16.7 \\
\hline
\end{tabular}

Analisis daya dukung tiang pancang dilakukan menggunakan data N-SPT yang diperoleh dari data proyek dan data N-SPT yang dikoreksi terhadap tegangan efektif dan terhadap efisiensi energi. Adapun metode koreksi N-SPT terhadap efisiensi energi adalah metode Skempton sedangkan metode koreksi N-SPT terhadap tegangan efektif adalah Metode Tokimatsu dan Yoshimi; Metode Liao dan Whitman; Metode Skempton; Metode Peck, Hansen dan Thornburn; dan Metode Bazaraa.

\section{Static Capacity}

$\underline{\text { Metode Meyerhoff }}$

- Tanah Non - Kohesif

$$
\begin{gathered}
\mathrm{Qp}=40 \times \mathrm{N} \times \frac{L b}{D} \times \mathrm{Ap} \\
\mathrm{Qs}=2 \times \mathrm{N} \times \mathrm{p} \times \mathrm{Li}
\end{gathered}
$$

Dengan $\mathrm{Q}_{\mathrm{p}}=$ daya dukung ujung tiang, $\mathrm{Q}_{\mathrm{s}}=$ daya dukung selimut tiang, $\mathrm{Q}_{\mathrm{s}}=$ kapasitas gesek selimut tiang, $\mathrm{N}=$ jumlah pukulan $(\mathrm{N}-\mathrm{SPT})$ yang telah dikoreksi, $\mathrm{Li}=$ panjang lapisan tanah, $\mathrm{p}=$ keliling tiang, $\mathrm{Ap}=$ uas penampang tiang.

Koreksi N-SPT Skempton dapat dihitung dengan persamaan:

$$
N_{60}=\frac{E_{H} C_{B} C_{S} C_{R} N}{0.6}
$$

Dengan $\mathrm{N}_{60}=$ nilai N-SPT koreksi, $\mathrm{E}_{\mathrm{H}}=$ efisiensi hammer borlog, $\mathrm{C}_{\mathrm{B}}=$ faktor koreksi diameter borehole, $\mathrm{C}_{\mathrm{S}}=$ faktor koreksi sampel, $\mathrm{C}_{\mathrm{R}}=$ faktor koreksi panjang tongkat.

- Tanah Kohesif

$$
\begin{gathered}
\mathrm{Qp}=9 \times \mathrm{Cu} \times \mathrm{Ap} \\
\mathrm{Qs}=\alpha \times \mathrm{Cu} \times \mathrm{p} \times \mathrm{Li}
\end{gathered}
$$

Dengan Qp = daya dukung ujung tiang, Qs = daya dukung selimut tiang, Li = panjang lapisan tanah, $\mathrm{p}=\mathrm{keliling}$ tiang, $\alpha=$ koefisien adhesi antara tanah dan tiang, $\mathrm{Cu}=$ kohesi undrained, Ap = luas penampang tiang.

\section{$\underline{\text { Metode Brown }}$}

$$
\begin{gathered}
f_{s}=F_{v s}\left(A_{b}+B_{b} \cdot N_{60}\right) \\
q_{p}=170 . N_{60}(k P a)
\end{gathered}
$$

Metode Schmertmann

Schmertmann menggunakan korelasi N-SPT dengan tahanan ujung qc untuk menentukan daya dukung gesekan dan daya dukung pondasi tiang. 
Tabel 2. Nilai Gesekan untuk Desain Pondasi

\begin{tabular}{lccc}
\hline \multicolumn{1}{c}{ Jenis Tanah } & Deskripsi & $\begin{array}{c}\text { Gesekan Selimut } \\
\left(\mathrm{kg} / \mathrm{cm}^{2}\right)\end{array}$ & $\begin{array}{c}\text { Tahanan Ujung } \\
\left(\mathrm{kg} / \mathrm{cm}^{2}\right)\end{array}$ \\
\hline Pasir Bersih & GW, GP, GM, SW, SP, SM & $0.019 \mathrm{~N}$ & $3.2 \mathrm{~N}$ \\
\hline $\begin{array}{l}\text { Lempung lanau bercampur pasir, } \\
\text { pasir kelanauan, lanau }\end{array}$ & GC, SC, ML, CL & $0.04 \mathrm{~N}$ & $1.6 \mathrm{~N}$ \\
\hline $\begin{array}{l}\text { Lempung plastis } \\
\text { Batu gemping rapuh, pasir } \\
\text { berkarang }\end{array}$ & $\mathrm{CH}, \mathrm{OH}$ & $0.05 \mathrm{~N}$ & $0.7 \mathrm{~N}$ \\
\hline
\end{tabular}

\section{Dynamic Capacity}

Metode Danish Formula

$$
\begin{gathered}
Q u=\frac{e_{h \times E_{h}}}{s+C_{1}} \\
C_{1}=\sqrt{\frac{e_{h \times E_{h} \times L}}{2 \times A p \times E}}
\end{gathered}
$$

Dengan $\mathrm{e}_{\mathrm{h}}=$ efisiensi hammer Eh = energi hammer, $\mathrm{s}=$ penetrasi pukulan per $\mathrm{cm}, \mathrm{L}=$ panjang tiang, $\mathrm{E}=$ modulus elastisitas tiang, Ap = luas penampang tiang.

Metode Eytelwein Formula

$$
R=\frac{2 E}{S+0.1\left(\frac{P}{W}\right)}
$$

Dengan $\mathrm{R}=$ Safe pile working load, $\mathrm{E}=$ Energi hammer, $\mathrm{S}=$ Pile set, $\mathrm{W}=$ Ram weight .

$\underline{\text { Metode Janbu }}$

$$
\begin{gathered}
Q u=\frac{e_{h} E_{h}}{K_{u}^{\prime} s} \\
K_{u}^{\prime}=C_{d}\left(1+\sqrt{1+\frac{\lambda^{\prime}}{C_{d}}}\right) \\
C_{d}=0.75+0.14\left(\frac{W_{p}}{W_{r}}\right) \\
\lambda^{\prime}=\frac{e_{h} E_{h} L}{A_{p} E s^{2}}
\end{gathered}
$$

Dengan $\mathrm{e}_{\mathrm{h}}=$ efisiensi hammer Eh = energi hammer $\mathrm{s}=$ penetrasi pukulan per $\mathrm{cm}, \mathrm{W}_{\mathrm{r}}=$ berat hammer, $\mathrm{W}_{\mathrm{p}}=$ berat tiang, $\mathrm{E}=$ modulus elastisitas tiang, $\mathrm{Ap}=$ luas penampang tiang.

\section{Modified ENR Formula}

$$
Q u=\frac{e_{h W r h\left(W r+n^{2} W p\right)}}{(s+0,25)(W r+W p)}
$$

Dengan $\mathrm{e}_{\mathrm{h}}=$ efisiensi hammer, $\mathrm{W}_{\mathrm{r}}=$ berat hammer, $\mathrm{h}=$ tinggi jatuh $\mathrm{ram}(\mathrm{cm}), \mathrm{s}=$ penetrasi pukulan per $\mathrm{cm}, \mathrm{n}=$ koefisien restitusi antara ram dan pile, $\mathrm{W}_{\mathrm{P}}=$ berat tiang.

Metode Gates

$$
Q_{u}=a \sqrt{E H_{e}}(b-\log S)
$$

Dengan $\mathrm{Qu}=$ Hammer of efficiency, $\mathrm{E}=$ Manufactures hammer rating, $\mathrm{a}=104.5, \mathrm{e}=$ Point penetration per blow, $\mathrm{b}$ $=2.4$. 


\section{Koreksi Terhadap Daya Dukung}

Pada tanah pasir dengan tingkat kepadatan yang sama tetapi pada kedalaman yang makin dalam akan mempunyai nilai N-SPT lebih tinggi. Umumnya koreksi nilai N-SPT dilakukan dengan mengambil nilai ekuivalennya terhadap tegangan vertical efektif sebesar $1 \mathrm{~kg} / \mathrm{cm}^{2}$.

$$
\mathrm{N}_{1}=\mathrm{C}_{\mathrm{N}} \mathrm{x} \mathrm{N}-\mathrm{SPT}
$$

Dengan $\mathrm{C}_{\mathrm{N}}=$ faktor koreksi.

$\underline{\text { Tokimatsu dan Yoshimi }}$

$\underline{\text { Liao dan Whitman }}$

$$
C_{N}=\frac{1.7}{0.7+\sigma_{v}^{\prime}}
$$

Skempton

$$
\begin{gathered}
C_{N}=\sqrt{\frac{p_{a}}{\sigma_{v}^{\prime}}}, p_{a}=100 \mathrm{kPa} \\
C_{N}=\sqrt{\frac{1}{\sigma_{v}^{\prime}}}, \sigma_{v}^{\prime}\left(\mathrm{ton} / \mathrm{ft}^{2} \text { atau } \mathrm{kg} / \mathrm{cm}^{2}\right)
\end{gathered}
$$

- Terhadap Tegangan Efektif

$$
C_{N}=\frac{n}{1+0.01 \sigma_{v}^{\prime}} \sigma_{v}^{\prime}\left(\frac{k N}{m^{2}}\right)
$$

Dengan $\mathrm{N}=2$ untuk pasir lepas, $\mathrm{N}=3$ untuk pasir padat.

- Terhadap Efisiensi Energi

Peck, Hansen dan Thornburn

$$
\begin{gathered}
\mu=\frac{E_{a}}{E_{\text {in }}} \\
N_{60}=\mu . N S P T \\
N_{60}=\frac{E_{a}}{60 \%} x N S P T
\end{gathered}
$$

Bazaraa

$$
\begin{gathered}
C_{N}=0.77 \log \left(\frac{2000}{\sigma_{v}^{\prime}}\right), \sigma_{v}^{\prime}\left(\frac{k N}{m^{2}}\right) \\
C_{N}=0.77 \log \left(\frac{20}{\sigma_{v}^{\prime}}\right), \sigma_{v}^{\prime}\left(\frac{k g}{m^{2}}\right)
\end{gathered}
$$

$$
\begin{gathered}
C_{N}=\frac{4}{1+2 \sigma_{v}^{\prime}} \sigma_{v}^{\prime}(k s f) \leq 1.5 \\
C_{N}=\frac{4}{3.25+0.5 \sigma_{v}^{\prime}} \sigma_{v}^{\prime}(k s f)>1.5
\end{gathered}
$$

\section{HASIL ANALISIS}

Analisis daya dukung tiang pancang dilakukan menggunakan data N-SPT yang diperoleh dari data proyek dan data N-SPT yang dikoreksi terhadap tegangan efektif dan terhadap efisiensi energi. Adapun metode koreksi N-SPT terhadap efisiensi energi adalah metode Skempton sedangkan metode koreksi N-SPT terhadap tegangan efektif adalah Metode Tokimatsu dan Yoshimi, Metode Liao dan Whitman, Metode Skempton, Metode Peck, Hansen dan Thornburn dan Metode Bazaraa.

Berikut ini adalah contoh tabel koreksi N-SPT yang dilakukan dimana koreksi yang dilakukan akan bekerja secara otomatis dengan melakukan input pada kolom berwarna kuning yaitu kolom N-SPT, jenis tanah dan n. Nilai N-SPT dan jenis tanah yang perlu di input adalah nilai N-SPT dan jenis tanah yang diperoleh dari data hasil boring log di lapangan sedangkan nilai n adalah konstanta untuk pasir. 
Tabel 2. Contoh Koreksi N-SPT

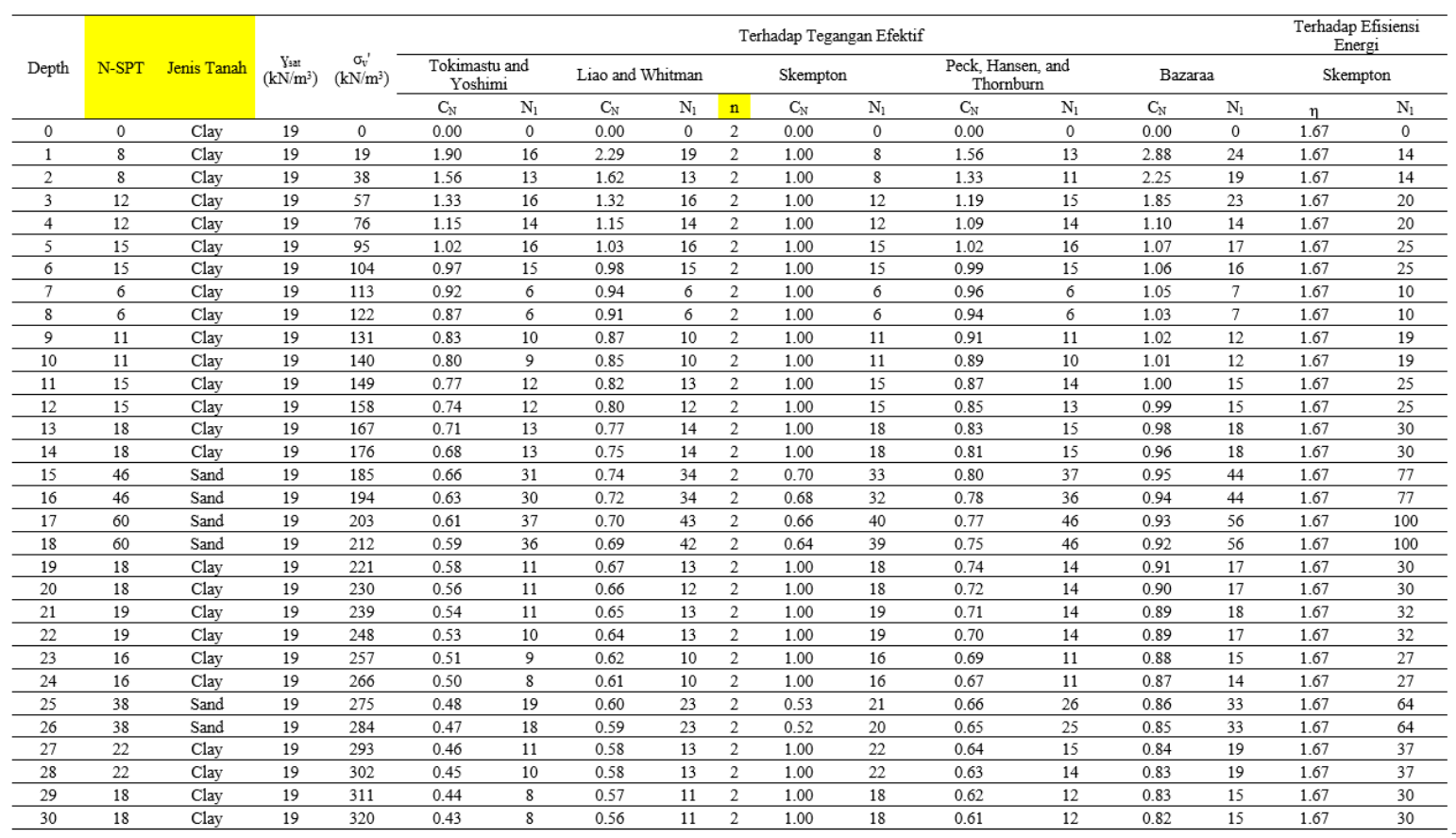

Dengan melakukan koreksi seperti penjelasan diatas, diperoleh hasil N-SPT terkoreksi boring log 1 sampai 5 untuk masing-masing metode koreksi.

Static Capacity

Berikut merupakan contoh tabel analisis daya dukung statik tiang pancang dengan metode Schmertmann, metode Brown dan metode Meyerhoff. Pada tabel ini, analisis akan dilakukan secara otomatis dengan meng-input nilai pada kolom berwarna kuning.

Tabel 3. Contoh Analisis Static Capacity

\begin{tabular}{|c|c|c|c|c|c|c|c|c|c|c|c|c|c|c|c|c|c|}
\hline \multirow[b]{2}{*}{ Kedalaman (m) } & \multirow{2}{*}{$\begin{array}{l}\mathrm{N}- \\
\text { SPT }\end{array}$} & \multicolumn{5}{|c|}{ Metode Schmertmann } & \multicolumn{6}{|c|}{ Metode Brown } & \multicolumn{5}{|c|}{ Metode Meyerhoff } \\
\hline & & Gesekan Selimut & Tahanan Ujung & $\begin{array}{c}\mathrm{Q}_{\mathrm{s}} \\
\text { (ton) }\end{array}$ & $\begin{array}{c}\mathrm{Q}_{\mathrm{b}} \\
\text { (ton) }\end{array}$ & $\begin{array}{l}Q_{\text {all }} \\
\text { (ton) }\end{array}$ & $F_{v s}$ & $A_{b}$ & $\mathrm{~B}_{\mathrm{b}}$ & $\mathrm{Q}_{\mathrm{s}}$ (ton) & $\mathrm{Q}_{\mathrm{b}}$ (ton) & Qall (ton) & $\mathrm{A}_{\mathrm{s}}\left(\mathrm{m}^{2}\right)$ & $\mathrm{N}$ & $\mathrm{Q}_{\mathrm{s}}$ (ton) & $\mathrm{Q}_{\mathrm{D}}$ (ton) & $\mathrm{Q}_{\text {all }}(\mathrm{ton})$ \\
\hline 0 & 0 & $0.04 \mathrm{~N}$ & $1.6 \mathrm{~N}$ & 0.00 & 0.00 & 0.00 & 1 & 26.6 & 1.92 & 2.66 & 0.00 & 0.89 & 0.00 & 0.00 & 0.00 & 0.00 & 0.00 \\
\hline 1 & 8 & $0.04 \mathrm{~N}$ & $1.6 \mathrm{~N}$ & 6.03 & 36.21 & 14.08 & 1 & 26.6 & 1.92 & 4.20 & 136.00 & 46.73 & 1.89 & 4.00 & 1.51 & 90.51 & 30.67 \\
\hline 2 & 8 & $0.04 \mathrm{~N}$ & $1.6 \mathrm{~N}$ & 12.07 & 36.21 & 16.09 & 1 & 26.6 & 1.92 & 4.20 & 136.00 & 46.73 & 3.77 & 5.33 & 4.02 & 90.51 & 31.51 \\
\hline 3 & 12 & $0.04 \mathrm{~N}$ & $1.6 \mathrm{~N}$ & 21.12 & 54.31 & 25.14 & 1 & 26.6 & 1.92 & 4.96 & 204.00 & 69.65 & 5.66 & 7.00 & 7.92 & 135.77 & 47.90 \\
\hline 4 & 12 & $0.04 \mathrm{~N}$ & $1.6 \mathrm{~N}$ & 30.17 & 54.31 & 28.16 & 1 & 26.6 & 1.92 & 4.96 & 204.00 & 69.65 & 7.54 & 8.00 & 12.07 & 135.77 & 49.28 \\
\hline 5 & 15 & $0.04 \mathrm{~N}$ & $1.6 \mathrm{~N}$ & 41.49 & 67.89 & 36.46 & 1 & 26.6 & 1.92 & 5.54 & 255.00 & 86.85 & 9.43 & 9.17 & 17.29 & 169.71 & 62.33 \\
\hline 6 & 15 & $0.04 \mathrm{~N}$ & $1.6 \mathrm{~N}$ & 52.80 & 67.89 & 40.23 & 1 & 26.6 & 1.92 & 5.54 & 255.00 & 86.85 & 11.31 & 10.00 & 22.63 & 169.71 & 64.11 \\
\hline 7 & 6 & $0.04 \mathrm{~N}$ & $1.6 \mathrm{~N}$ & 57.33 & 27.15 & 28.16 & 1 & 26.6 & 1.92 & 3.81 & 102.00 & 35.27 & 13.20 & 9.50 & 25.08 & 67.89 & 30.99 \\
\hline 8 & 6 & $0.04 \mathrm{~N}$ & $1.6 \mathrm{~N}$ & 61.85 & 27.15 & 29.67 & 1 & 26.6 & 1.92 & 3.81 & 102.00 & 35.27 & 15.09 & 9.11 & 27.49 & 67.89 & 31.79 \\
\hline 9 & 11 & $0.04 \mathrm{~N}$ & $1.6 \mathrm{~N}$ & 70.15 & 49.78 & 39.98 & 1 & 26.6 & 1.92 & 4.77 & 187.00 & 63.92 & 16.97 & 9.30 & 31.57 & 124.46 & 52.01 \\
\hline 10 & 11 & $0.04 \mathrm{~N}$ & $1.6 \mathrm{~N}$ & 78.45 & 49.78 & 42.74 & 1 & 26.6 & 1.92 & 4.77 & 187.00 & 63.92 & 18.86 & 9.45 & 35.66 & 124.46 & 53.37 \\
\hline 11 & 15 & $0.04 \mathrm{~N}$ & $1.6 \mathrm{~N}$ & 89.76 & 67.89 & 52.55 & 1 & 26.6 & 1.92 & 5.54 & 255.00 & 86.85 & 20.74 & 9.92 & 41.14 & 169.71 & 70.28 \\
\hline 12 & 15 & $0.04 \mathrm{~N}$ & $1.6 \mathrm{~N}$ & 101.07 & 67.89 & 56.32 & 1 & 26.6 & 1.92 & 5.54 & 255.00 & 86.85 & 22.63 & 10.31 & 46.65 & 169.71 & 72.12 \\
\hline 13 & 18 & $0.04 \mathrm{~N}$ & $1.6 \mathrm{~N}$ & 114.65 & 81.46 & 65.37 & 1 & 26.6 & 1.92 & 6.12 & 306.00 & 104.04 & 24.51 & 10.86 & 53.23 & 203.66 & 85.63 \\
\hline 14 & 18 & $0.04 \mathrm{~N}$ & $1.6 \mathrm{~N}$ & 128.23 & 81.46 & 69.90 & 1 & 26.6 & 1.92 & 6.12 & 306.00 & 104.04 & 26.40 & 11.33 & 59.84 & 203.66 & 87.83 \\
\hline 15 & 46 & $0.019 \mathrm{~N}$ & $3.2 \mathrm{~N}$ & 144.71 & 416.37 & 187.03 & 1 & 26.6 & 1.92 & 11.49 & 782.00 & 264.50 & 28.29 & 13.50 & 76.37 & 520.46 & 198.94 \\
\hline 16 & 46 & $0.019 \mathrm{~N}$ & $3.2 \mathrm{~N}$ & 161.19 & 416.37 & 192.52 & 1 & 26.6 & 1.92 & 11.49 & 782.00 & 264.50 & 30.17 & 15.41 & 93.00 & 520.46 & 204.49 \\
\hline 17 & 60 & $0.019 \mathrm{~N}$ & $3.2 \mathrm{~N}$ & 182.69 & 543.09 & 241.92 & 1 & 26.6 & 1.92 & 14.18 & 1020.00 & 344.73 & 32.06 & 17.89 & 114.69 & 678.86 & 264.52 \\
\hline 18 & 60 & $0.019 \mathrm{~N}$ & $3.2 \mathrm{~N}$ & 204.19 & 543.09 & 249.09 & 1 & 26.6 & 1.92 & 14.18 & 1020.00 & 344.73 & 33.94 & 20.11 & 136.49 & 678.86 & 271.78 \\
\hline 19 & 18 & $0.04 \mathrm{~N}$ & $1.6 \mathrm{~N}$ & 217.76 & 81.46 & 99.74 & 1 & 26.6 & 1.92 & 6.12 & 306.00 & 104.04 & 35.83 & 20.00 & 143.31 & 203.66 & 115.66 \\
\hline 20 & 18 & $0.04 \mathrm{~N}$ & $1.6 \mathrm{~N}$ & 231.34 & 81.46 & 104.27 & 1 & 26.6 & 1.92 & 6.12 & 306.00 & 104.04 & 37.71 & 19.90 & 150.14 & 203.66 & 117.93 \\
\hline 21 & 19 & $0.04 \mathrm{~N}$ & $1.6 \mathrm{~N}$ & 245.67 & 85.99 & 110.55 & 1 & 26.6 & 1.92 & 6.31 & 323.00 & 109.77 & 39.60 & 19.86 & 157.32 & 214.97 & 124.10 \\
\hline 22 & 19 & $0.04 \mathrm{~N}$ & $1.6 \mathrm{~N}$ & 260.00 & 85.99 & 115.33 & 1 & 26.6 & 1.92 & 6.31 & 323.00 & 109.77 & 41.49 & 19.83 & 164.50 & 214.97 & 126.49 \\
\hline 23 & 16 & $0.04 \mathrm{~N}$ & $1.6 \mathrm{~N}$ & 272.07 & 72.41 & 114.83 & 1 & 26.6 & 1.92 & 5.73 & 272.00 & 92.58 & 43.37 & 19.67 & 170.59 & 181.03 & 117.21 \\
\hline 24 & 16 & $0.04 \mathrm{~N}$ & $1.6 \mathrm{~N}$ & 284.14 & 72.41 & 118.85 & 1 & 26.6 & 1.92 & 5.73 & 272.00 & 92.58 & 45.26 & 19.52 & 176.68 & 181.03 & 119.24 \\
\hline 25 & 38 & $0.019 \mathrm{~N}$ & $3.2 \mathrm{~N}$ & 297.75 & 343.95 & 213.90 & 1 & 26.6 & 1.92 & 9.96 & 646.00 & 218.65 & 47.14 & 20.23 & 190.75 & 429.94 & 206.90 \\
\hline 26 & 38 & $0.019 \mathrm{~N}$ & $3.2 \mathrm{~N}$ & 311.37 & 343.95 & 218.44 & 1 & 26.6 & 1.92 & 9.96 & 646.00 & 218.65 & 49.03 & 20.89 & 204.83 & 429.94 & 211.59 \\
\hline 27 & 22 & $0.04 \mathrm{~N}$ & $1.6 \mathrm{~N}$ & 327.96 & 99.57 & 142.51 & 1 & 26.6 & 1.92 & 6.88 & 374.00 & 126.96 & 50.91 & 20.93 & 213.11 & 248.91 & 154.01 \\
\hline 28 & 22 & $0.04 \mathrm{~N}$ & $1.6 \mathrm{~N}$ & 344.56 & 99.57 & 148.04 & 1 & 26.6 & 1.92 & 6.88 & 374.00 & 126.96 & 52.80 & 20.97 & 221.40 & 248.91 & 156.77 \\
\hline 29 & 18 & $0.04 \mathrm{~N}$ & $1.6 \mathrm{~N}$ & 358.13 & 81.46 & 146.53 & 1 & 26.6 & 1.92 & 6.12 & 306.00 & 104.04 & 54.69 & 20.87 & 228.22 & 203.66 & 143.96 \\
\hline 30 & 18 & $0.04 \mathrm{~N}$ & $1.6 \mathrm{~N}$ & 371.71 & 81.46 & 151.06 & 1 & 26.6 & 1.92 & 6.12 & 306.00 & 104.04 & 56.57 & 20.77 & 235.05 & 203.66 & 146.23 \\
\hline
\end{tabular}


Analisis dengan metode Schmertmann, metode Brown dan metode Meyerhoff ini dilakukan dengan menggunakan data N-SPT asli yang diperoleh dari data 5 buah boring log dan N-SPT terkoreksi dari masing-masing boring log yang dikoreksi menggunakan 6 metode koreksi yang telah disebutkan sebelumnya. Berdasarkan hasil analisis, berikut merupakan contoh grafik daya dukung tiang.

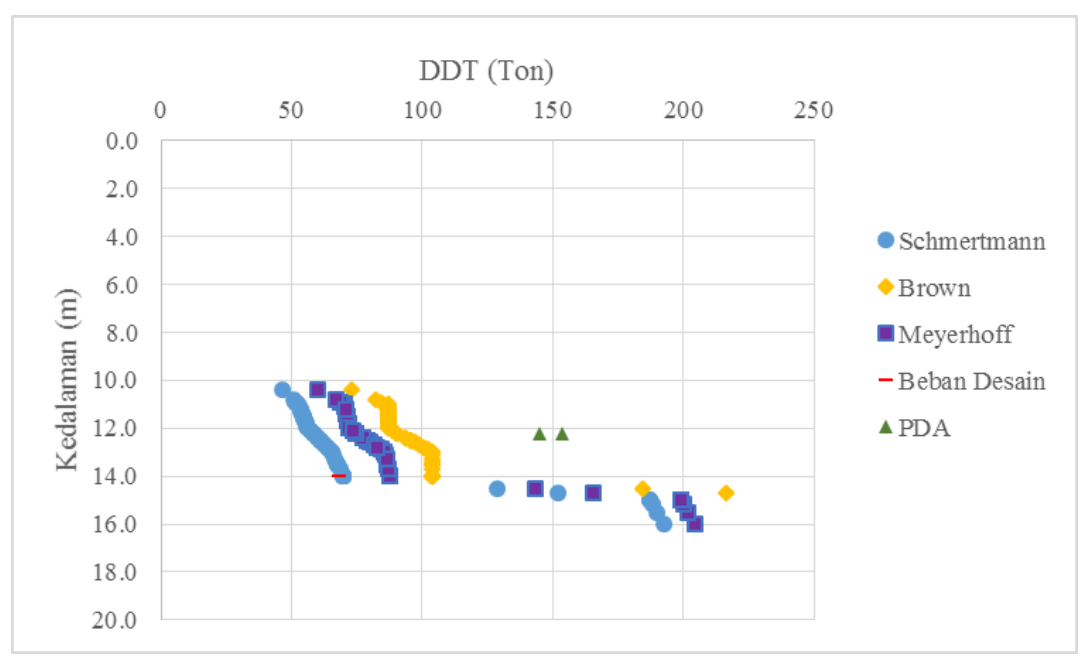

Gambar 2. Grafik DDT vs Kedalaman BL47D N-SPT Asli

Dynamic Capacity

Analisis dynamic capacity ini dilakukan menggunakan 6 metode, antara lain Danish Formula, Eytelwein Formula, Gates Formula, Janbu, Modified ENR Formula, Navy Mc-Kay Formula. Berdasarkan keenam metode tersebut diperoleh dynamic capacity tiang pancang terhadap boring log 1-5. Berikut adalah contoh hasil analisis.

Tabel 4. Contoh Analisis Dynamic Capacity

\begin{tabular}{|c|c|c|c|c|c|c|c|c|c|c|c|c|c|c|}
\hline \multirow{2}{*}{ Name } & \multirow{2}{*}{ Final Set (mm) } & \multirow{2}{*}{ Panjang Pile (m) } & \multirow{2}{*}{$\begin{array}{l}\text { Wp } \\
(\mathrm{kN})\end{array}$} & \multicolumn{2}{|c|}{ Danish Formula } & \multirow{2}{*}{$\begin{array}{c}\text { Eytelwwein Formula } \\
P_{\mathrm{s}} \text { (ton) }\end{array}$} & \multirow{2}{*}{$\begin{array}{c}\text { Gates Formula } \\
P_{u} \text { (ton) }\end{array}$} & \multicolumn{4}{|c|}{ Janbu } & \multirow{2}{*}{$\begin{array}{c}\text { Modified ENR Formula } \\
\mathrm{P}_{u} \text { (ton) }\end{array}$} & \multicolumn{2}{|c|}{ Navy Mc-Kay Formula } \\
\hline & & & & $\mathrm{C}_{1}$ & $P_{u}($ ton) & & & $\mathrm{C}_{\mathrm{a}}$ & $x$ & $\mathrm{~K}_{\mathrm{u}}$ & $\mathrm{P}_{\mathrm{a}}$ (ton) & & $\mathrm{C}_{1}$ & $P_{u}(\operatorname{ton})$ \\
\hline \multicolumn{15}{|c|}{ BL1 } \\
\hline 1 Blok PS-11L & 52.67 & 14.00 & 95.04 & 0.06 & 211.92 & 118.67 & 205.67 & 1.01 & 256.25 & 17.12 & 152.48 & 85.85 & 1.73 & 143.28 \\
\hline 2 Blok PS-11L & 41.33 & 14.00 & 95.04 & 0.06 & 215.69 & 134.45 & 218.57 & 1.01 & 416.05 & 21.52 & 154.55 & 100.43 & 1.73 & 182.57 \\
\hline 3 Blok PS-11L & 134.00 & 14.00 & 95.04 & 0.06 & 188.32 & 64.41 & 155.98 & 1.01 & 39.59 & 7.41 & 138.48 & 42.04 & 1.73 & 56.32 \\
\hline 4 Blok PS-11L & 47.00 & 14.00 & 95.04 & 0.06 & 213.79 & 126.07 & 211.73 & 1.01 & 321.77 & 19.06 & 153.51 & 92.57 & 1.73 & 160.56 \\
\hline 5 Blok PS-11L & 160.00 & 14.00 & 95.04 & 0.06 & 181.84 & 56.20 & 146.54 & 1.01 & 27.77 & 6.40 & 134.32 & 36.15 & 1.73 & 47.16 \\
\hline 6Blok PS-11L & 4.33 & 10.40 & 70.60 & 0.05 & 265.37 & 310.20 & 338.59 & 0.94 & 28119.19 & 163.74 & 193.78 & 254.26 & 1.28 & 1909.06 \\
\hline 1 Blok PS-12L & 110.00 & 14.00 & 95.04 & 0.06 & 194.72 & 74.46 & 166.48 & 1.01 & 58.74 & 8.77 & 142.46 & 49.50 & 1.73 & 68.60 \\
\hline 2 Blok PS-12L & 45.00 & 14.00 & 95.04 & 0.06 & 214.46 & 128.90 & 214.05 & 1.01 & 351.01 & 19.86 & 153.87 & 95.20 & 1.73 & 167.70 \\
\hline 3 Blok PS-12L & 98.00 & 14.00 & 95.04 & 0.06 & 198.08 & 80.75 & 172.63 & 1.01 & 74.01 & 9.71 & 144.49 & 54.31 & 1.73 & 77.00 \\
\hline 4 Blok PS-12L & 40.00 & 14.00 & 95.04 & 0.06 & 216.14 & 136.59 & 220.31 & 1.01 & 444.24 & 22.21 & 154.79 & 102.48 & 1.73 & 188.66 \\
\hline 5 Blok PS-12L & 102.00 & 14.00 & 95.04 & 0.06 & 196.95 & 78.54 & 170.50 & 1.01 & 68.32 & 9.37 & 143.81 & 52.61 & 1.73 & 73.98 \\
\hline 6 Blok PS-12L & 8.00 & 14.00 & 95.04 & 0.06 & 227.59 & 220.81 & 305.96 & 1.01 & 11106.10 & 106.88 & 160.81 & 200.66 & 1.73 & 943.29 \\
\hline 1 Blok PS-13L & 9.50 & 16.00 & 108.62 & 0.06 & 212.58 & 192.06 & 296.82 & 1.05 & 9000.91 & 98.09 & 147.55 & 181.55 & 1.97 & 757.41 \\
\hline 2 Blok PS-13L & 12.33 & 15.50 & 105.22 & 0.06 & 214.98 & 188.07 & 282.93 & 1.04 & 5173.50 & 74.29 & 150.07 & 170.19 & 1.91 & 590.27 \\
\hline 3 Blok PS-13L & 9.00 & 13.40 & 90.97 & 0.06 & 232.17 & 224.63 & 299.70 & 1.00 & 8399.11 & 92.56 & 165.05 & 198.40 & 1.65 & 850.93 \\
\hline 4 Blok PS-13L & 9.00 & 12.50 & 84.86 & 0.06 & 240.25 & 237.78 & 299.70 & 0.98 & 7834.99 & 88.68 & 172.29 & 204.16 & 1.54 & 870.32 \\
\hline 5 Blok PS-13L & 8.00 & 13.10 & 88.93 & 0.06 & 235.18 & 233.51 & 305.96 & 0.99 & 10392.14 & 102.56 & 167.59 & 206.26 & 1.62 & 964.46 \\
\hline 6 Blok PS-13L & 12.00 & 15.20 & 103.19 & 0.06 & 217.16 & 192.08 & 284.39 & 1.03 & 5359.14 & 75.39 & 152.00 & 173.12 & 1.88 & 610.98 \\
\hline 1 Blok PS-14L & 11.00 & 15.00 & 101.83 & 0.06 & 218.92 & 197.47 & 289.02 & 1.03 & 6293.90 & 81.46 & 153.45 & 178.87 & 1.85 & 669.70 \\
\hline 3 Blok PS-14L & 11.00 & 14.70 & 99.79 & 0.06 & 221.11 & 200.72 & 289.02 & 1.02 & 6168.02 & 80.43 & 155.41 & 180.40 & 1.81 & 674.51 \\
\hline 4 Blok PS-14L & 35.50 & 13.50 & 91.65 & 0.06 & 221.45 & 147.23 & 226.67 & 1.00 & 543.86 & 24.34 & 159.12 & 111.72 & 1.67 & 215.20 \\
\hline 5 Blok PS-14L & 90.00 & 15.00 & 101.83 & 0.06 & 194.46 & 83.62 & 177.16 & 1.03 & 94.02 & 10.91 & 140.02 & 56.42 & 1.85 & 81.85 \\
\hline 6 Blok PS-14L & 9.00 & 14.00 & 95.04 & 0.06 & 227.22 & 216.64 & 299.70 & 1.01 & 8775.19 & 95.12 & 160.61 & 194.82 & 1.73 & 838.48 \\
\hline 3 Blok PS-15L & 10.00 & 14.50 & 98.43 & 0.06 & 222.96 & 206.61 & 294.09 & 1.02 & 7361.76 & 87.61 & 156.94 & 186.56 & 1.79 & 745.54 \\
\hline 4 Blok PS-15L & 7.00 & 13.00 & 88.25 & 0.06 & 236.47 & 239.93 & 313.07 & 0.99 & 13469.79 & 116.51 & 168.59 & 213.30 & 1.60 & 1104.99 \\
\hline 5 Blok PS-15L & 4.50 & 11.70 & 79.43 & 0.05 & 250.23 & 278.25 & 336.58 & 0.97 & 29334.22 & 169.36 & 180.42 & 241.28 & 1.44 & 1776.61 \\
\hline 6Blok PS-15L & 12.00 & 12.50 & 84.86 & 0.06 & 239.00 & 223.85 & 284.39 & 0.98 & 4407.18 & 66.76 & 171.64 & 187.78 & 1.54 & 652.74 \\
\hline 3 Blok PS-16L & 7.00 & 13.50 & 91.65 & 0.06 & 232.10 & 232.31 & 313.07 & 1.00 & 13987.86 & 119.27 & 164.69 & 210.00 & 1.67 & 1091.35 \\
\hline 4 Blok PS-16L & 7.00 & 13.50 & 91.65 & 0.06 & 232.10 & 232.31 & 313.07 & 1.00 & 13987.86 & 119.27 & 164.69 & 210.00 & 1.67 & 1091.35 \\
\hline 5 Blok PS-16L & 5.67 & 11.00 & 74.67 & 0.05 & 257.44 & 285.37 & 324.32 & 0.95 & 17392.06 & 129.74 & 187.02 & 238.02 & 1.36 & 1436.82 \\
\hline 6 Blok PS-16L & 4.33 & 11.10 & 75.35 & 0.05 & 256.93 & 292.81 & 338.59 & 0.96 & 30011.83 & 170.30 & 186.32 & 247.80 & 1.37 & 1873.99 \\
\hline 3 Blok PS-17L & 6.00 & 12.90 & 87.57 & 0.06 & 237.79 & 246.72 & 321.27 & 0.99 & 18192.85 & 135.12 & 169.60 & 220.79 & 1.59 & 1292.39 \\
\hline 4 Blok PS-17L & 12.67 & 13.00 & 88.25 & 0.06 & 234.19 & 214.48 & 281.51 & 0.99 & 4113.70 & 64.84 & 167.42 & 181.55 & 1.60 & 610.65 \\
\hline 5 Blok PS-17L & 5.00 & 11.80 & 80.11 & 0.05 & 248.95 & 272.86 & 330.98 & 0.97 & 23963.80 & 153.31 & 179.37 & 236.50 & 1.46 & 1594.83 \\
\hline 6 Blok PS-17L & 9.00 & 12.60 & 85.54 & 0.06 & 239.31 & 236.24 & 299.70 & 0.98 & 7897.67 & 89.11 & 171.45 & 203.49 & 1.56 & 868.12 \\
\hline 1 Blok PS-11R & 8.33 & 12.40 & 84.18 & 0.06 & 241.49 & 242.72 & 303.79 & 0.98 & 9065.63 & 95.22 & 173.28 & 208.88 & 1.53 & 942.33 \\
\hline 2 Blok PS-11R & 10.00 & 11.70 & 79.43 & 0.05 & 247.75 & 245.46 & 294.09 & 0.97 & 5940.18 & 76.75 & 179.16 & 203.79 & 1.44 & 799.47 \\
\hline 3 Blok PS-11R & 5.00 & 11.80 & 80.11 & 0.05 & 248.95 & 272.86 & 330.98 & 0.97 & 23963.80 & 153.31 & 179.37 & 236.50 & 1.46 & 1594.83 \\
\hline
\end{tabular}




\section{KESIMPULAN}

Berdasarkan kajian teknis, analisis, dan pembahasan dari proyek konstruksi jalan tol JKC dapat disimpulkan bahwa:

1. Dilakukan studi N-SPT lapangan dengan N-SPT koreksi dari berbagai metode ditunjukkan pada grafik berikut.

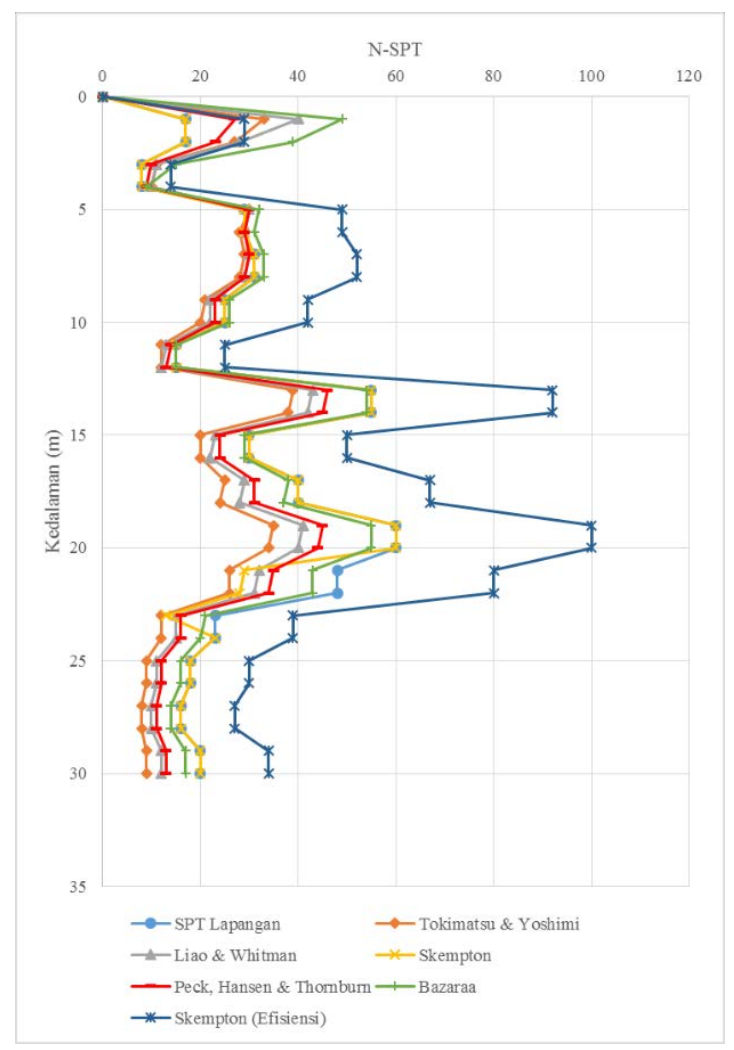

Gambar 3. Contoh Grafik N-SPT Koreksi Zona A

2. Studi N-SPT koreksi untuk perhitungan daya dukung dengan berbagai metode memberikan hasil sebagai berikut:

Tabel 5. Metode Analisis N-SPT Koreksi dan Daya Dukung Tiang yang Paling Mendekati Hasil Uji PDA dan Beban Desain

\begin{tabular}{|c|c|c|c|c|c|c|}
\hline Deskripsi & Zona & A & B & C & $\mathrm{D}$ & E \\
\hline \multirow{2}{*}{$\begin{array}{l}\text { Faktor N-SPT koreksi untuk daya } \\
\text { dukung tiang yang mendekati hasil PDA }\end{array}$} & N-SPT Koreksi & Bazaraa & Skempton (Efisiensi) & $\begin{array}{l}\text { Tokimastu and } \\
\text { Yoshimi }\end{array}$ & Bazaraa & Liao and Whitman \\
\hline & Daya Dukung & Semua & Brown & Schmertmann & Meyerhoff & Schmertmann \\
\hline \multirow{2}{*}{$\begin{array}{l}\text { Faktor N-SPT koreksi untuk daya } \\
\text { dukung tiang yang mendekati beban } \\
\text { desain }\end{array}$} & N-SPT Koreksi & $\begin{array}{l}\text { Tokimastu and } \\
\text { Yoshimi }\end{array}$ & $\begin{array}{l}\text { Tokimastu and } \\
\text { Yoshimi }\end{array}$ & $\begin{array}{l}\text { Tokimastu and } \\
\text { Yoshimi }\end{array}$ & $\begin{array}{l}\text { Tokimastu and } \\
\text { Yoshimi }\end{array}$ & $\begin{array}{l}\text { Tokimastu and } \\
\text { Yoshimi }\end{array}$ \\
\hline & Daya Dukung & Schmertmann & Meyerhoff & Schmertmann & Schmertmann & Schmertmann \\
\hline
\end{tabular}

\begin{tabular}{llcc}
\hline \multirow{2}{*}{ Deskripsi } & Zona & D & E \\
\hline $\begin{array}{l}\text { Faktor N-SPT koreksi untuk daya } \\
\text { dukung tiang yang mendekati hasil PDA }\end{array}$ & N-SPT Koreksi & Bazaraa & Liao and Whitman \\
\cline { 2 - 4 } $\begin{array}{l}\text { Faktor N-SPT koreksi untuk daya } \\
\text { dukung tiang yang mendekati beban } \\
\text { desain }\end{array}$ & N-SPT Koreksi & $\begin{array}{c}\text { Mokimastu and } \\
\text { Yoshimi }\end{array}$ & $\begin{array}{c}\text { Tokimastu and } \\
\text { Yoshimi }\end{array}$ \\
\cline { 2 - 4 } & Daya Dukung & Schmertmann & Schmertmann \\
\hline
\end{tabular}


3. Berdasarkan studi N-SPT tersebut, maka 338 tiang yang terpancang memberikan gambaran persentase sebagai berikut:

Tabel 6. Persentase Tiang yang Melebihi Beban Desain

\begin{tabular}{ccccc}
\hline Metode Zona & A & B & C & D \\
\hline Schmertmann & 100 & 10.96 & 100 & 100 \\
\hline Brown & 100 & 95.89 & 100 & 100 \\
\hline Meyerhoff & 100 & 36.99 & 100 & 100 \\
\hline
\end{tabular}

4. Dilakukan analisis dinamik dengan hasil sebagai berikut:

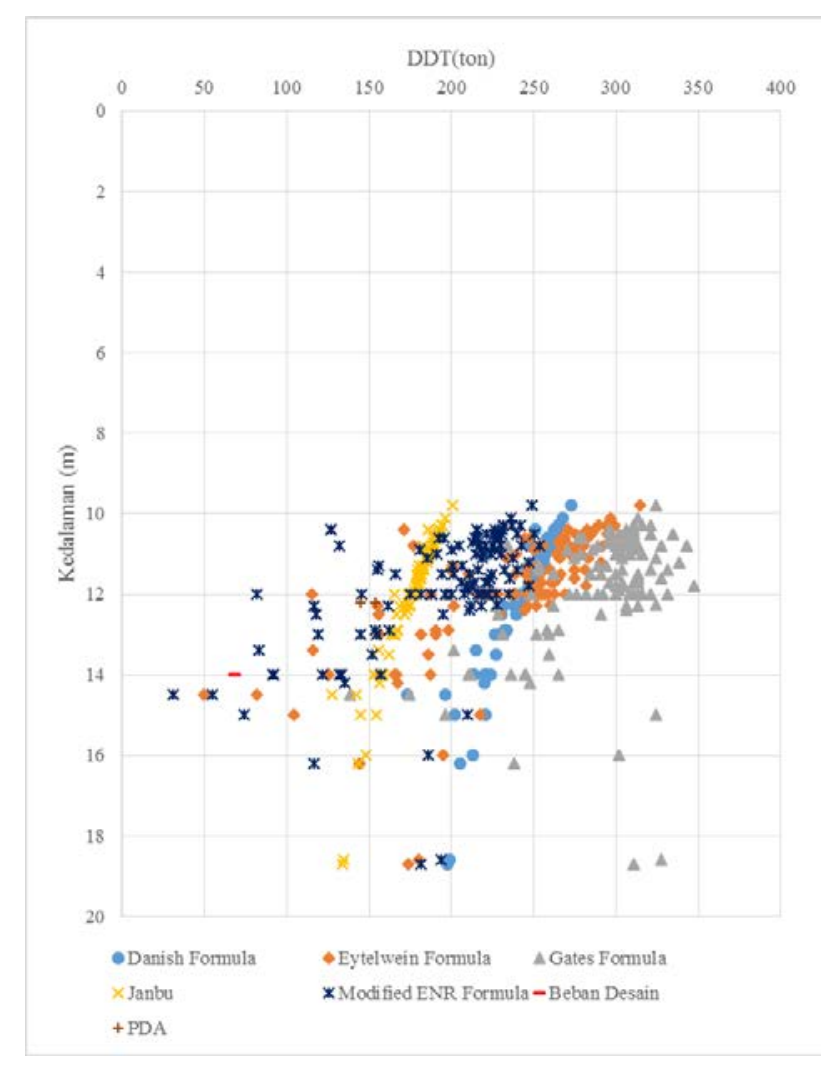

Gambar 4. Contoh Grafik DDT vs Kedalaman Zona A Pile Dynamic Formula

\section{DAFTAR PUSTAKA}

Bowles, J.E. (1988). Foundation Analysis and Design (Fifth Edition). McGraw-Hill Companies Inc, Singapore.

Deep Foundation Research Institute. (2013). Manual Pondasi Tiang Edisi 5. Geotechnical Engineering Center, Bandung.

Gunawan, Rudy. 1983. Pengantar Teknik Fondasi. Yogyakarta : Penerbit Kanisius. 
